\title{
Plants as a prospective source of natural anti-viral compounds and oral vaccines against COVID-
}

\section{9 coronavirus}

\author{
Mahdi Yonesi ${ }^{1}$, Alireza Rezazadeh ${ }^{2 *}$
}

1- Centro de Tecnología Biomédica (CTB), Universidad Politécnica de Madrid, Madrid, Spain

2- Faculty of Agricultural Sciences, Shahed University, Tehran, Iran

*For correspondence Email “Rezazadeh@Shahed.ac.ir"

\section{Abstract}

The proposal of novel drugs and approaches for effective treatment of the novel coronavirus is a necessity after the quick outbreak of the disease. Since the commencement of the coronavirus spread, enormous efforts have been made to protect, alleviate and cure the disease, though no specific treatment has been approved. While there have been convincing results in the use of chemical drugs and interferon therapy, such therapeutic approaches have various drawbacks and lack the required performance for the treatment of the new coronavirus. Medicinal plant species can provide a solution as a source of natural antiviral compounds by the accumulation of secondary metabolites and lectins as well as acting as a platform to express the viral immunogenic proteins. This study reviews the advantages and the results of previous research for the treatment of the novel coronavirus disease and previous generations of similar coronaviruses. Several plant-derived anti coronavirus compounds have been nominated that could be targeted for further research due to the similarity of the coronavirus disease in 2003 and the current coronavirus. This review regards plant species such as Scutellaria baicalensis (Baikal skullcap), and Utrica dioica (Stinging nettle) as suitable candidates for the new coronavirus antiviral research. Furthermore, the use of plants such as Nicotiana tabacum (Tobacco) for the expression of the coronavirus viral antigens can be a target for the future vaccinal research of the new coronavirus due to the efficiency of expression and intrinsic antiviral properties.

Keywords: 2019 Novel Coronavirus, Plants, Antiviral Compounds, Plant Recombinant Vaccines 


\section{Contents}



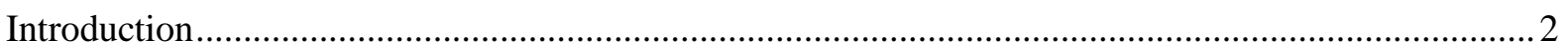

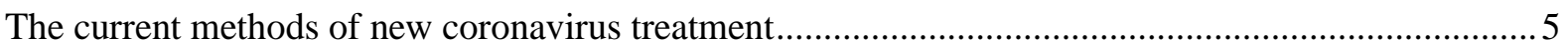

Plants have considerable potential for the treatment of the coronavirus related SARS disease .............5

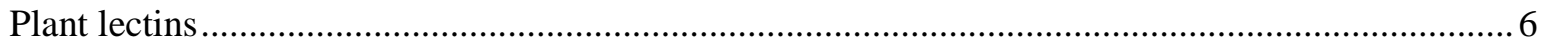

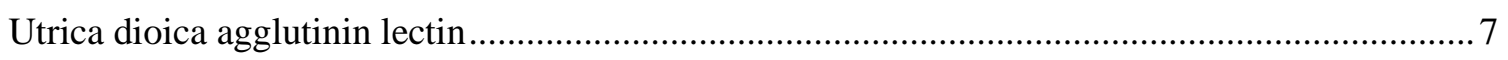

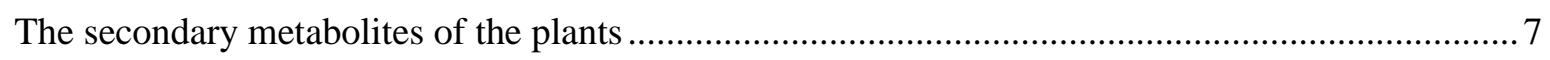

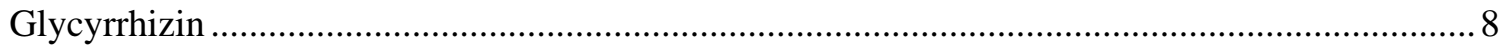

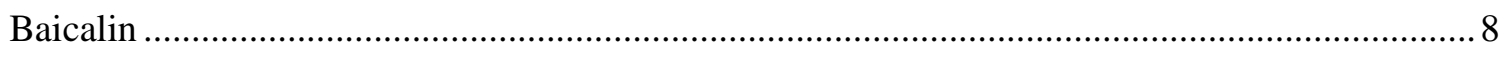

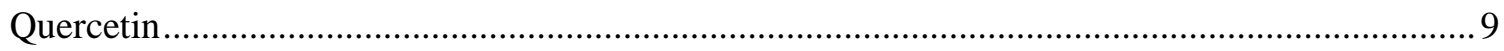

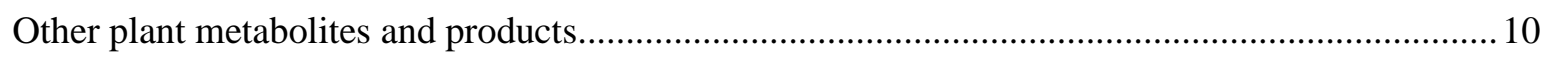

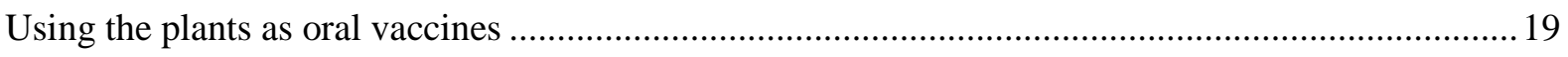

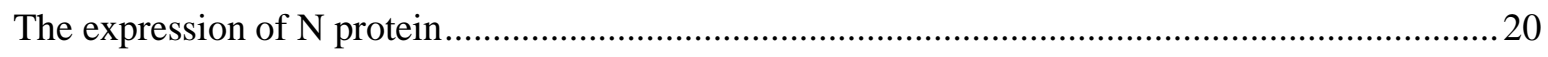

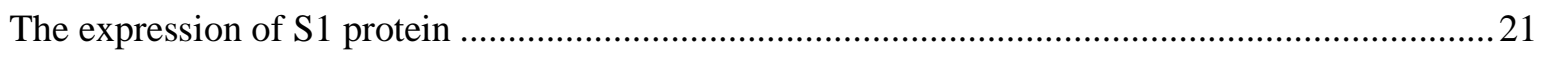

Controlling the plants' anti-viral compounds expression via environmental conditions ......................22

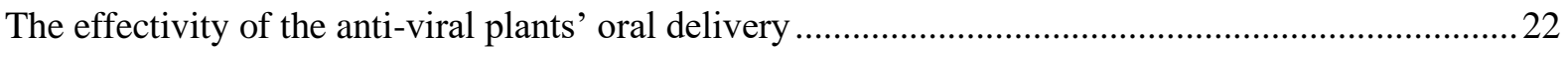



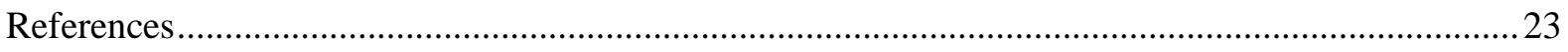

\section{Introduction}

The Coronaviridae family is composed of enveloped single-stranded RNA viruses that were normally regarded as the origin of types of common cold, upper respiratory disorders and lower respiratory 
infection in the case of the elderly and patients with a weak immune system. However, in 2003, the appearance of Severe Acute Respiratory Syndrome (SARS) caused by the coronavirus agent of SARSCov belonging to betacoronavirus subfamily, presented an urgent necessity of research about SARS related coronavirus. Nine years later another coronavirus appeared as Middle East Respiratory Syndrom (MERS) in Saudi Arabia with 2492 total laboratory-confirmed cases and 858 fatalities[1]. At present, The current outbreak caused by a new subtype of coronavirus named SARS-Cov2 has resulted in a pandemic with thousands of deaths and infected cases. This pandemic phenomenon is maintaining a sustained progression in the world, showing an emergency international alarm for finding an effective cure.

The SARS-Cov 2, SARS Cov and MERS Cov belong to the genera of the betacoronaviruses. At the first stage of the SARS-Cov coronavirus appearance, it was attempted to cure the disease by Ribavirin which revealed positive results in curing the patients. While drugs such as Aciclovir, Levofloxacin, Vancomycin, Caspofungin, and Meropenem were not able to show a significant relief in the patients [2]. The Lopinavir/Ritonavir with Ribavirin administration to the patients at the initial stages of the disease could reduce the mortality rate [3]. However, later it was confirmed that the Ribavirin treatment was associated with considerable toxicity and this approach was not successful to show compelling results in-vitro. Additionally, it was demonstrated by a recent study that the administration of Lopinavir/Ritonavir does not have a significant effect on the cases of COVID-19 [4]. The interferon therapy, the delivery of corticosteroid and immunoglobulins are the other methods that have been applied as the common treatment of the SARS-Cov. However, none of these approaches were successful in the treatment of SARS (2003). And new targeted anti-viral drugs were necessary. Therefore, it was sought to assess the structural properties of the SARS-related betacoronaviruses. 


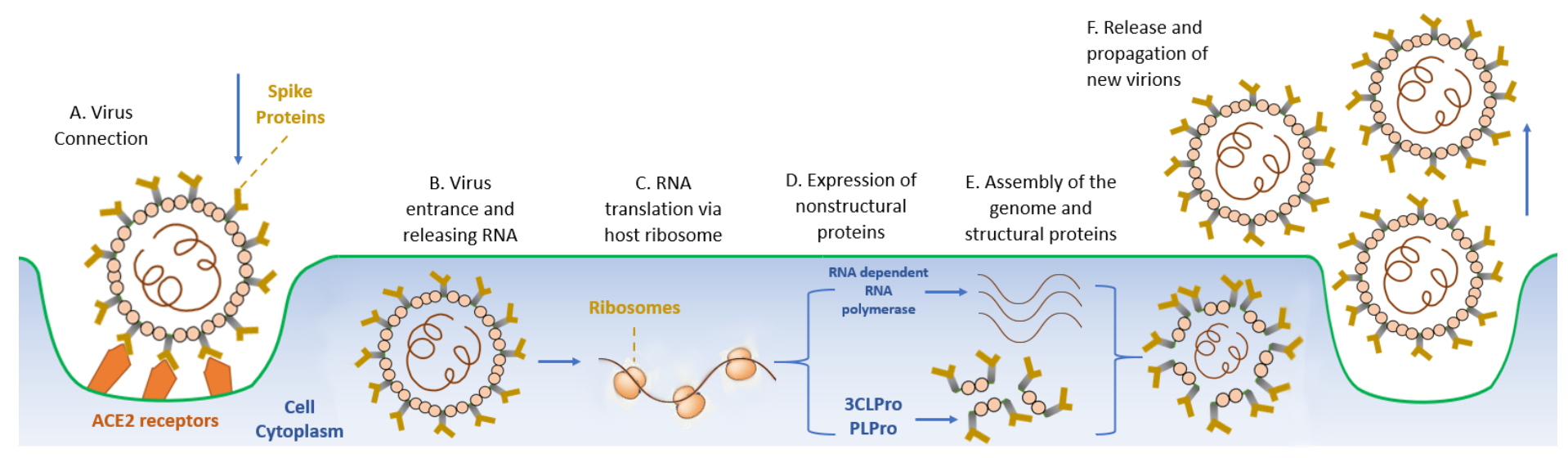

Figure 1. The schematic of the coronavirus viral cycle. The virus attaches to the ACE2 receptors of the human cells (A). It enters the cells and releases the RNA content (B). The translation of the RNA will be done using the host ribosomes of the cells $(\mathrm{C})$ which results in the expression of the essential enzymes to produce the RNA replication and packaging proteins. $3 \mathrm{CL}^{\text {Pro }}$ and $\mathrm{PL}^{\text {Pro }}$ have an essential function to process the non-structural proteins required for the processing of the viral polyproteins (D). The packaging proteins and the RNA content are assembled to produce new virions (E). The virions exit the cells for starting another cycle of viral infection.

Anand et al (2003) determined a protein with three domains and 304 residues as the main protease of the SARS-Cov and following by this study various research targeted this protease for inhibition of the SARS-Cov activity [6-8]. Later, this protease has been named 3C Like Protease (3CL ${ }^{\text {Pro }}$ ). Papain-Like protease $\left(\mathrm{PL}^{\mathrm{Pro}}\right)$ was demonstrated as another target enzyme for the symptoms caused by SARS-Cov. While RNA-dependent RNA polymerase has a significant role in the coding of the genomic content of coronavirus upon infection, the $3 \mathrm{CL}^{\text {Pro }}$ and $\mathrm{PL}^{\text {Pro }}$ are regarded as key enzymes in the processing of the nonstructural proteins of the virus (nsps) which is thought to have a main role in the establishment of the viral replication (Figure1; $[9,10]$. The surface of SARS-Cov is covered with the spike proteins that are able to attach to human Angiotensin-Converting Enzyme 2 receptors (ACE2). ACE2 receptors are normally expressed in the lungs, kidney, endothelium, heart, and intestine [11]. Targeting the SARSCov spike proteins as well as the blockage of human ACE2 proteins can be an alternative way to block the activity of the SARS-Cov. 


\section{The current methods of new coronavirus treatment}

A variety of the targets considering the inhibition of the RNA transcription, RNA modification, virus packaging enzymes, the capsid, and the surface proteins assist the virus to diffuse into the cells and can be regarded as strategies to deactivate or prohibit the propagation of RNA virus in cells and tissues [12]. The current methods of COVID-19 treatment are composed of the administration of drugs such as Remdesivir, Chloroquine, Arbidol, and Favipiravir and approaches such as interferon therapy [12, 13]. Currently, studies are focusing on further investigation of the biochemical materials that could inhibit the main proteases of the virus or the compounds that could inhibit the propagation rate of the virus in the cells. The plants provide an ultimate, natural source of enzyme and viral propagation inhibitors to be implicated as a treatment method of disorders caused by SARS-Cov and SARS-Cov2.

Fortunately, there is a considerable similarity between the SARS-Cov and SARS-Cov2 virus which is more than $80 \%$ identity and $96 \%$ similarity of the genome $[15,14]$. It has been confirmed that the PL Pro and $3 \mathrm{CL}^{\text {Pro }}$ of the SARS-Cov and SARS-Cov2 are conserved [16]. Additionally, it is observed that there is a $76.10 \%$ identity between the mentioned viruses [17]. Based on this similarity, it is expected that the results of the studies about the SARS-Cov could be implied for the research in the SARS-Cov2 to a high degree.

\section{Plants have considerable potential for the treatment of the coronavirus}

\section{related SARS disease}

Plants provide a wide source of viral protein inhibitors for the treatment of SARS. Generally, plants can express metabolites that can provide an inhibitory effect on the enzymes, proteins and the propagation of the virus. Although numerous studies have focused on the SARS 2003, there are a lower number of studies with the focus on the COVID-19 disease and mainly the articles are limited to in-silico studies of the plant compounds $[16,18]$. Hopefully, based on the fact that most of the active proteins in the infection cycle of SARS-Cov2 are conserved, it can be expected that the result of a variety of researches about previous generations of coronaviruses especially SARS-Cov could be applicable to the new 
coronavirus. Table 1 shows a selection of the approaches based on the plants, mentioning the representative agents based on our literature review that could have the value of further research for the COVID-19 disease. It is attempted to further discuss these strategies in the following sections.

Table 1. Potential antiviral strategies based on plants against new coronavirus.

\begin{tabular}{|c|c|c|c|}
\hline Approach & Effective agent* & Plant & References \\
\hline \multirow{2}{*}{$\begin{array}{l}\text { Using plant lectins for } \\
\text { inhibition of the virus } \\
\text { attachment }\end{array}$} & $\begin{array}{l}\text { Utrica dioica Agglutinin } \\
\text { (UDA) }\end{array}$ & $\begin{array}{l}\text { Utrica dioica (Stinging } \\
\text { nettle) }\end{array}$ & [19-21] \\
\hline & $\begin{array}{l}\text { Allium porrum } \\
\text { Agglutinin (APA) }\end{array}$ & Allium porrum (Leek) & [19] \\
\hline \multirow[t]{3}{*}{$\begin{array}{l}\text { Natural plant } \\
\text { secondary metabolites }\end{array}$} & Glycyrrhizin & $\begin{array}{l}\text { Glycyrrhiza glabra } \\
\text { (Licorice) }\end{array}$ & {$[22-24]$} \\
\hline & Baicalin & $\begin{array}{l}\text { Scutellaria baicalensis } \\
\text { (Baikal skullcap) }\end{array}$ & {$[22,25,26]$} \\
\hline & Quercetin & $\begin{array}{l}\text { Allium cepa (Onion) } \\
\text { Allium sativum (Garlic) }\end{array}$ & [27-29] \\
\hline \multirow{2}{*}{$\begin{array}{l}\text { Plant bioreactors: } \\
\text { Using plants to express } \\
\text { vaccinal proteins } \\
\text { (Plant Oral Vaccines) }\end{array}$} & Viral S1 Antigen & $\begin{array}{l}\text { Nicotiana tabacum } \\
\text { (Tobacco) } \\
\text { Tomato }\end{array}$ & [30-32] \\
\hline & Viral N Antigen & $\begin{array}{l}\text { Nicotiana tabacum } \\
\text { (Tobacco) }\end{array}$ & [33-35] \\
\hline
\end{tabular}

* The representative agents have been mentioned by various studies to have positive results in previous research.

\section{Plant lectins}

The plant immunity is an elaborate system that can efficiently detect and deactivate the invading pathogens with a variety of tools considering cell surface and intracellular receptor proteins. Plant lectins are carbohydrate-binding proteins that can act as immunologic receptors and defense proteins 
and are found in a variety of species such as tobacco, soy, and leek. Plant lectins can be regarded as one of the plant-based compounds that could be targeted as a treatment for COVID-19. There are a variety of plant compounds that has been found by several studies to inhibit the proliferation trend of the SARSCov.

\section{Utrica dioica agglutinin lectin}

Stinging nettle (Utrica dioica) has been used in various countries as traditional medicine for years. This plant has been reported to have therapeutic effects on cardiovascular, immunity, neuronal and digestive systems [36]. The agglutinin lectin is extracted from the rhizomes of the common stinging nettle. Previously it was indicated that from the lectins that have been extracted from the selective plant species, the Allium porrum Agluttinin (APA) of Leek, Utrica dioica Agglutinin (UDA) of stinging nettle and NICTABA lectin of Tobacco (Nicotiana tabacum) was able to show the highest inhibition tendency to prohibit the proliferation rate of the virus to $50 \%$ (EC50) at less than $1.3 \mu \mathrm{g} / \mathrm{ml}$ pure extract with low toxicity in-vitro [19]. Similarly, further studies confirmed that the UDA has an impact on the inhibition of the SARS-Cov virus in-vitro [20]. Experiments have proposed that the lectins will interrupt the viral attachment and the effect of lectins has the highest performance when they are delivered at the early stages of the infection cycle [19]. Later the antiviral effect of the UDA has been assessed in-vivo in Bulb C mouse models and it was found that the UDA significantly decreased the mortality caused by SARS and reduced the weight loss [21]. This study also proposed that the UDA prevents the virus attachment by inhibition of the SARS-CoV spike (S) glycoprotein [21]. The evidence from the previous research shows that UDA can be a suitable compound for further research in the COVID-19 arena.

\section{The secondary metabolites of the plants}

Secondary metabolites are considered as non-necessary compounds for plant cells living. Such metabolites are expressed in response to biotic and abiotic stresses. The expression of the secondary metabolites is increased upon stress appearance. Plant active compounds such as Trashinones, Flavonoids, Carotenoids, and Diaryheptanoids can be regarded as examples. There is a variety of plant secondary metabolites that have been studied for the inhibition of SARS-Cov that are found to have a 
strong antiviral and anti-SARS-Cov activity. Some of the important examples of such compounds have been discussed in the following.

\section{Glycyrrhizin}

Glycyrrhizin is the major component in the licorice (Glycyrrhiza glabra) root. This compound has been used traditionally for the treatment of gastritis, bronchitis, and jaundice and is reported to have antioxidant and anti-inflammatory activity that can stimulate the formation of interferons in the body [37]. It has been proposed that Glycyrrhizin can decrease the attachment of the SARS-Cov agents to the cells especially during the initial phase of the viral infection cycle [39]. Glycyrrhizin is composed of Flavonoids, Glycyrrhetinic acid, $\beta$-sitosterol and hydroxyl coumarins [37] and has been observed to have a significant anti-SARS-Cov activity by Cinatl et al (2003). Later Pilcher (2003) regarded the licorice plant and Glycyrrhizin as a prospective method of making a commercial drug against SARSCov, adding the fact that there is a long way until making a commercial drug for the SARS-Cov. The anti-SARS-Cov activity of Glycyrrhizin was further confirmed by other studies [22-24] and numerous review articles have been published as a result of positive antiviral activity of Glycyrrhizin [40-42]. The in-silico study for prediction of Glycyrrhizin behavior for COVID-19 disease has noted the Glycyrrhizin as a potential inhibitor of SARS-Cov2 [18, 43]. However, no studies have been found in the SARSCov, for approval of the in-vivo effectiveness of the Glycyrrhizin. Yet, based on the promising results of the mentioned studies this compound might be a potential for the development of an anti-COVID-19 disease drug.

\section{Baicalin}

Baicalin is one of the major constituents of the plants in the Scutellaria genus and is the main origin of the Scutellaria baicalensis pharmaceutical properties. This Flavone glucuronide is previously found to have anti-apoptotic and antioxidant properties and has been previously used for the treatment of pulmonary atrial hypertension. The anti-SARS-Cov activity of this compound was first shown by Chen et al. (2004) with a stronger inhibitory effect compared to Glycyrrhizin, Interferon-alpha, and Interferon-beta 1a and considerably low toxicity concentration for the cell lines in-vitro. The anti-viral activity of this compound was found so important that later a grant for the patent of anti-SARS drug 
production with this biochemical compound was approved [26]. The in-vitro assessment of the extracted flavonoids from the Scutellaria baicalensis also showed significant anti-viral activity on the Lipopolysaccharide activated cells while the oral administration of the compound significantly increased the survival rate of influenza A virus-infected mice [25]. Furthermore, the in-vivo result confirmed the anti-viral activity of the Baicalin in-vivo environment. However, no in-vivo study was noticed for the effect of Baicalin on SARS-Cov infected model animals. The in-silico study of the Baicalin for simulation of the compound effect in the case of COVID-19 disease demonstrated a favorable tendency of Baicalin to inhibit Angiotensin-converting enzyme 2 (ACE2). The extract of the Scutellaria baicalensis was able to inhibit the $3 \mathrm{CL}^{\text {Pro }}$ activity of the new SARS-Cov2 virus in-vitro in a recent investigation which further approves the potential of this compound for additional studies in COVID-19 disease [44].

\section{Quercetin}

Organosulfur compounds are amply found in the plants of the Allium genus such as onions (e.g. Allium cepa), garlic (e.g. Allium sativum) and leek (Allium porrum). Generally, organosulfur compounds are the organic macromolecules that contain sulfur in their biochemical structure. In a recent in-silico study for SARS-Cov2, it was revealed that the organosulfur materials from the A.porrum can have significant potential in inhibition of the Human ACE2 enzymes and therefore can it can have the potential to inhibit the connection of the SARS-Cov2 to the cells [45].

Quercetin is a flavonoid that is abundantly discovered in the onion and garlic species and can be found as sulfonic substituents (although less occurring) [27]. Quercetin-3- $\beta$-galactoside was shown by Chen et al. (2006) to have inhibition activity of $3 \mathrm{CL}^{\text {Pro }}$ of SARS-Cov. Further studies confirmed the inhibition of $3 \mathrm{CL}^{\text {Pro }}$ of the SARS-Cov by both Quercetin and Quercetin-3- $\beta$-galactoside in-vitro $[28,29]$. It was also noticed that quercetin 3- $\beta$-D-glucoside has the potential to inhibit the $3 \mathrm{CL}^{\text {Pro }}$ of the MERS-Cov [47]. This compound is found to have low toxicity to the cells in-vitro, and it is one of the major natural components that is targeted for the treatment of the COVID-19 disease. 


\section{Other plant metabolites and products}

Scutellarein is another ample natural flavone in the Scutellaria genus. This compound is observed to have the anti-viral, anti-inflammatory and antioxidant ability. As this metabolite is also discovered in the Scutellaria baicalensis it might be possible that various anti-viral features in the reports about the anti-SARS properties of the S. baicalensis extract were the outcome of Scutellarein presence alongside the Baicalin [48]. Later, this compound was found to have an inhibitory effect on nsP13 coronavirus helicase activity. Additionally, in a recent study, the antiviral activity of this compound was assessed in-vitro and a strong replication inhibition was shown for the case of novel COVID-19 disease. Such results indicate the strong potential of plant species such as S. baicalensis to be used against SARS-Cov agent.

Li et al. (2005) assessed a variety of the herbal extracts in organic solvents such as ethanol and chloroform and they were able to show the extract of Lycoris radiata as the plant that encounters the highest anti-SARS-Cov activity with a significantly lower dose of effectiveness (about 2.1 to $2.4 \mathrm{ug} / \mathrm{ml}$ ). This study proposes that the antiviral activity of the extracts is due to the presence of Lycorine in the L.radiata plant [49]. Hesperetin is another flavonoid that is observed to have an inhibitory effect on the SARS-Cov $3 \mathrm{CL}^{\text {Pro }}[50]$. Hesperetin is normally found in the species of citrus (Lemons) genus in-vitro. Chen et al (2006) revealed that the selective terpenoids and Lignoids extracted from plants such as Juniperus formosana, Cryptomeria japonica and Chamaecyparis obtuse showed a significant inhibitory effect for 3CL protease of SARS-Cov [51].

Apart from the examples that were represented in the plants that might show compelling antiviral activity against COVID-19 disease, many other studies have assessed the antiviral activity of different plants and biochemical metabolites against the previous generation of SARS related coronavirus, considerably SARS-Cov and MERS-Cov that each might provide a solution against the new COVID19 disease. Table 2 presents the overview of the studies that have been done against SARS-related coronavirus especially SARS-Cov. 
Table2. Plants with the potential of the anti-SARS-Cov activity.

\begin{tabular}{|c|c|c|c|c|c|}
\hline Family & Name & $\begin{array}{l}\text { Inhibition } \\
\text { approach }\end{array}$ & $\begin{array}{l}\text { Effective } \\
\text { Compound }\end{array}$ & $\begin{array}{l}\text { Inhibition } \\
\text { potential } \\
(\text { IC50/EC50)* }\end{array}$ & Reference \\
\hline Amaryllidaceae & $\begin{array}{l}\text { Allium sativum } \\
\text { (Garlic) }\end{array}$ & $\begin{array}{l}\text { ACE2 } \\
\text { receptor } \\
\text { inhibitor }\end{array}$ & Allyl trisulfide & - & [45] \\
\hline Anacardiaceae & $\begin{array}{l}\text { Galla chinensis } \\
\text { (Nutgall tree) }\end{array}$ & $\begin{array}{l}\text { Viral spike } \\
\text { protein and } \\
\text { human } \\
\text { ACE2 } \\
\text { receptors } \\
\text { inhibitor }\end{array}$ & $\begin{array}{l}\text { Tetra- } O \text {-galloyl- } \\
\beta \text {-d-glucose }\end{array}$ & $4.5-240 \mu \mathrm{M}$ & [52] \\
\hline Apiaceae & $\begin{array}{l}\text { Angelica } \\
\text { keiskei } \\
\text { (Ashitaba) }\end{array}$ & $\begin{array}{l}3 \mathrm{CL}^{\text {pro }} \\
\text { Inhibitor }\end{array}$ & Chalcones & $11.4-129.8 \mu \mathrm{M}$ & [53] \\
\hline Betulaceae & $\begin{array}{l}\text { Betula } \\
\text { pubescens } \\
\text { (Downy birch) }\end{array}$ & $\begin{array}{l}3 \mathrm{CL}^{\text {pro }} \\
\text { Inhibitor }\end{array}$ & Betulinic acid & $8.2 \pm 0.7 \mu \mathrm{M}$ & [51] \\
\hline Betulaceae & $\begin{array}{l}\text { Alnus japonica } \\
\text { (East Asian } \\
\text { alder) }\end{array}$ & $\begin{array}{l}\text { PL }^{\text {pro }} \\
\text { inhibitor }\end{array}$ & Plant extract & $4.1 \mathrm{uM}$ & [54] \\
\hline
\end{tabular}




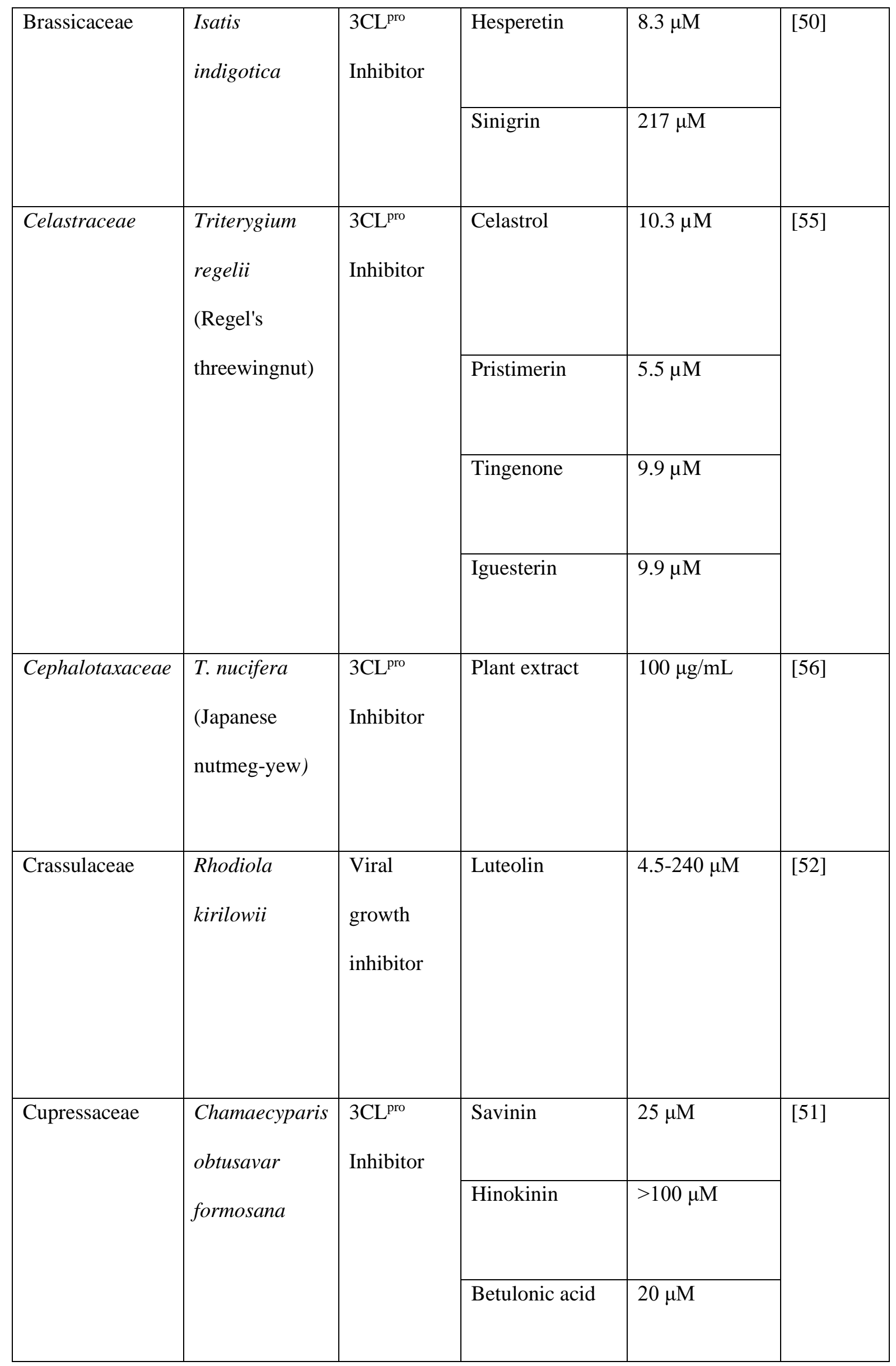




\begin{tabular}{|c|c|c|c|c|c|}
\hline & $\begin{array}{l}\text { (Formosan } \\
\text { Hinoki } \\
\text { Cypress) }\end{array}$ & & & & \\
\hline Cupressaceae & $\begin{array}{l}\text { Cryptomeria } \\
\text { japonica } \\
\text { (Japanese } \\
\text { cedar) }\end{array}$ & $\begin{array}{l}\text { Viral } \\
\text { growth } \\
\text { inhibitor }\end{array}$ & $\begin{array}{l}\text { Hydroxy-deoxy- } \\
\text { cryptojaponol }\end{array}$ & $>10 \mu \mathrm{M}$ & [51] \\
\hline Cupressaceae & $\begin{array}{l}\text { Thuja } \\
\text { orientalis }\end{array}$ & $\begin{array}{l}\text { Viral } \\
\text { growth } \\
\text { Inhibitor }\end{array}$ & Plant extract & $\begin{array}{l}130 \pm 1.2 \\
\mathrm{ug} / \mathrm{ml}\end{array}$ & [57] \\
\hline Cupressaceae & $\begin{array}{l}\text { Juniperus } \\
\text { oxycedrus } \\
\text { (Cade) }\end{array}$ & $\begin{array}{l}\text { Viral } \\
\text { growth } \\
\text { Inhibitor }\end{array}$ & Plant extract & $\begin{array}{l}130 \pm 1.2 \\
\mathrm{ug} / \mathrm{ml}\end{array}$ & [57] \\
\hline Dioscoreaceae & $\begin{array}{l}\text { Dioscoreae } \\
\text { Rhizoma } \\
\text { (Cinnamon- } \\
\text { vine) }\end{array}$ & $\begin{array}{l}\text { Viral } \\
\text { growth } \\
\text { inhibitor }\end{array}$ & Plant extract & $200 \mu \mathrm{g} / \mathrm{ml}$ & [58] \\
\hline Fabaceae & $\begin{array}{l}\text { Glycyrrhiza } \\
\text { glabra. } \\
\text { (Liquorice) }\end{array}$ & $\begin{array}{l}\text { Viral } \\
\text { growth } \\
\text { inhibitor }\end{array}$ & Glycyrrhizin & $30 \mathrm{ug} / \mathrm{ml}$ & {$[24,38]$} \\
\hline
\end{tabular}




\begin{tabular}{|c|c|c|c|c|c|}
\hline Fabaceae & $\begin{array}{l}\text { Pterocarpus } \\
\text { santalinus } \\
\text { (Red sanders) }\end{array}$ & $\begin{array}{l}\text { 3CL } \\
\text { Inhibitor }\end{array}$ & Savinin & $9.1 \pm 2.4 \mu \mathrm{M}$ & [51] \\
\hline Fabaceae & $\begin{array}{l}\text { Cassiae Semen } \\
\text { (Sickle Senna) }\end{array}$ & $\begin{array}{l}\text { Viral } \\
\text { growth } \\
\text { inhibitor }\end{array}$ & Plant extract & $200 \mu \mathrm{g} / \mathrm{ml}$ & [58] \\
\hline Fabaceae & $\begin{array}{l}\text { Psoralea } \\
\text { corylifolia }\end{array}$ & $\begin{array}{l}\text { PL }^{\text {pro }} \\
\text { inhibitor }\end{array}$ & Plant extract & $15 \mu \mathrm{g} / \mathrm{ml}$ & [59] \\
\hline Gentianaceae & $\begin{array}{l}\text { Gentianae } \\
\text { Radix } \\
\text { (Gentian) }\end{array}$ & $\begin{array}{l}\text { Viral } \\
\text { growth } \\
\text { inhibitor }\end{array}$ & Plant extract & $200 \mu \mathrm{g} / \mathrm{ml}$ & [58] \\
\hline Lamiaceae & $\begin{array}{l}\text { Salvia } \\
\text { miltiorrhiza } \\
\text { (Red sage) }\end{array}$ & $\begin{array}{l}\text { PL }^{\text {pro }} \\
\text { inhibitor }\end{array}$ & Tanshinones & $0.8-30.0 \mu \mathrm{M}$ & [60] \\
\hline Lamiaceae & $\begin{array}{l}\text { Scutellaria } \\
\text { baicalensis } \\
\text { (Georgi } \\
\text { Baikal } \\
\text { skullcap) }\end{array}$ & $\begin{array}{l}\text { Viral } \\
\text { growth } \\
\text { inhibitor }\end{array}$ & Plant extract & - & $\begin{array}{l}{[61]} \\
{[62]}\end{array}$ \\
\hline
\end{tabular}




\begin{tabular}{|c|c|c|c|c|c|}
\hline Lamiaceae & $\begin{array}{l}\text { Scutellaria } \\
\text { lateriflora } \\
\text { (blue skullcap) }\end{array}$ & $\begin{array}{l}\text { Helicase } \\
\text { inhibitor }\end{array}$ & Scutellarein & - & [63] \\
\hline Lauraceae & $\begin{array}{l}\text { Laurus nobilis } \\
\text { (Laurel) }\end{array}$ & $\begin{array}{l}\text { Viral } \\
\text { Growth } \\
\text { inhibitor }\end{array}$ & Plant Extract & $120 \mu \mathrm{g} / \mathrm{ml}$ & [57] \\
\hline Lauraceae & $\begin{array}{l}\text { Cinnamomum } \\
\text { cassia (Cortex } \\
\text { Chinese cassia) }\end{array}$ & $\begin{array}{l}3 \mathrm{CL}^{\text {pro }} \\
\text { Inhibitor }\end{array}$ & Plant extract & $\begin{array}{l}30.3 \pm 2.6 \\
\mu \mathrm{g} / \mathrm{ml}\end{array}$ & [64] \\
\hline Lauraceae & $\begin{array}{l}\text { Cinnamomum } \\
\text { cassia (Cortex } \\
\text { Chinese cassia) }\end{array}$ & $\begin{array}{l}3 \mathrm{CL}^{\text {pro }} \\
\text { Inhibitor }\end{array}$ & Plant extract & $\begin{array}{l}30.3 \pm 2.6 \\
\mu \mathrm{g} / \mathrm{ml}\end{array}$ & [64] \\
\hline Linaceae & $\begin{array}{l}\text { Linum } \\
\text { usitatissimum } \\
\text { (Flax) }\end{array}$ & $\begin{array}{l}3 \mathrm{CL}^{\text {pro }} \\
\text { Inhibitor }\end{array}$ & Herbacetin & - & [65] \\
\hline Loranthaceae & $\begin{array}{l}\text { Loranthi } \\
\text { Ramus } \\
\text { (Mulberry) }\end{array}$ & $\begin{array}{l}\text { Viral } \\
\text { growth } \\
\text { inhibitor }\end{array}$ & Plant extract & $200 \mu \mathrm{g} / \mathrm{ml}$ & [58] \\
\hline Meliaceae & $\begin{array}{l}\text { Toona sinensis } \\
\text { Roem } \\
\text { (Chinese cedar) }\end{array}$ & $\begin{array}{l}\text { Inhibit the } \\
\text { cellular } \\
\text { entry of }\end{array}$ & Quercetin & - & [58] \\
\hline
\end{tabular}




\begin{tabular}{|c|c|c|c|c|c|}
\hline & & $\begin{array}{l}\text { SARS- } \\
\mathrm{CoV}\end{array}$ & & & \\
\hline Menispermaceae & $\begin{array}{l}\text { Stephania } \\
\text { cepharantha } \\
\text { Hayata }\end{array}$ & $\begin{array}{l}\text { Viral } \\
\text { Growth } \\
\text { inhibitor }\end{array}$ & Biscoclaurine & - & {$[66]$} \\
\hline Myricaceae & $\begin{array}{l}\text { Myrica faya } \\
\text { (Bayberry) }\end{array}$ & $\begin{array}{l}\text { Helicase } \\
\text { inhibitor }\end{array}$ & Myricetin & - & {$[63]$} \\
\hline Paulowniaceae & $\begin{array}{l}\text { Paulownia } \\
\text { tomentosa } \\
\text { (Princess tree) }\end{array}$ & $\begin{array}{l}\text { PL }^{\text {pro }} \\
\text { inhibitor }\end{array}$ & Flavonoids & $5.0 \mu \mathrm{M}$ & [67] \\
\hline Plantaginaceae & $\begin{array}{l}\text { Veronica } \\
\text { linariifolia }\end{array}$ & $\begin{array}{l}\text { Viral } \\
\text { growth } \\
\text { inhibitor }\end{array}$ & Luteolin & $4.5-240 \mu \mathrm{M}$ & {$[52]$} \\
\hline Polygonaceae & $\begin{array}{l}\text { Rheum } \\
\text { palmatum } \\
\text { (Ornamental } \\
\text { rhubarb) }\end{array}$ & & Plant extract & $\begin{array}{l}13.76 \pm 0.03 \\
\mu \mathrm{g} / \mathrm{ml}\end{array}$ & [68] \\
\hline Polygonaceae & $\begin{array}{l}\text { Rheum } \\
\text { officinale }\end{array}$ & $\begin{array}{l}\text { Viral spike } \\
\text { protein and }\end{array}$ & Emodin & $1-10 \mu \mathrm{g} / \mathrm{ml}$ & [69] \\
\hline
\end{tabular}




\begin{tabular}{|c|c|c|c|c|c|}
\hline & (Rhubarb) & $\begin{array}{l}\text { human } \\
\text { ACE2 } \\
\text { receptors } \\
\text { inhibitor }\end{array}$ & & & \\
\hline Polygonaceae & $\begin{array}{l}\text { Reynoutria } \\
\text { (Multiflora } \\
\text { Tuber) }\end{array}$ & $\begin{array}{l}\text { Viral spike } \\
\text { protein and } \\
\text { human } \\
\text { ACE2 } \\
\text { receptors } \\
\text { inhibitor }\end{array}$ & Emodin & $1-10 \mu \mathrm{g} / \mathrm{ml}$ & [69] \\
\hline Santalales & $\begin{array}{l}\text { Rhizoma } \\
\text { Cibotii (Showy } \\
\text { mistletoes) }\end{array}$ & $\begin{array}{l}3 \mathrm{CL}^{\text {pro }} \\
\text { Inhibitor }\end{array}$ & Plant extract & $200 \mu \mathrm{g} / \mathrm{ml}$ & [58] \\
\hline Sapindaceae & $\begin{array}{l}\text { Litchi chinensis } \\
\text { (Lichi) }\end{array}$ & $\begin{array}{l}3 \mathrm{CL}^{\text {pro }} \\
\text { Inhibitor }\end{array}$ & $\begin{array}{l}\text { Flavonoids } \\
\text { extract }\end{array}$ & - & [65] \\
\hline Saururaceae & $\begin{array}{l}\text { Houttuynia } \\
\text { cordata } \\
\text { (Fish leaf) }\end{array}$ & $\begin{array}{l}3 \mathrm{CL}^{\text {pro }} \\
\text { Inhibitor } \\
\text { and RNA- } \\
\text { dependent } \\
\text { RNA } \\
\text { polymerase } \\
\text { (RdRp) } \\
\text { Inhibitor }\end{array}$ & Plant extract & $>200 \mu \mathrm{g} / \mathrm{ml}$ & {$[70,71]$} \\
\hline
\end{tabular}




\begin{tabular}{|c|c|c|c|c|c|}
\hline Saururaceae & $\begin{array}{l}\text { Houttuynia } \\
\text { cordata } \\
\text { (Fish mint) }\end{array}$ & $\begin{array}{l}3 \mathrm{CL}^{\text {pro }} \\
\text { Inhibitor }\end{array}$ & Plant extract & $50 \mu \mathrm{g} / \mathrm{ml}$ & [70] \\
\hline Solanaceae & $\begin{array}{l}\text { Nicotiana } \\
\text { benthamiana } \\
\text { (Benth) }\end{array}$ & $\begin{array}{l}\text { Viral } \\
\text { growth } \\
\text { inhibitor }\end{array}$ & $\begin{array}{l}\text { NICTABA } \\
\text { Lectin }\end{array}$ & - & {$[33,72]$} \\
\hline \multirow[t]{2}{*}{ Theaceae } & \multirow[t]{2}{*}{$\begin{array}{l}\text { Camellia } \\
\text { sinensis } \\
\text { (Black tea) }\end{array}$} & \multirow[t]{2}{*}{$\begin{array}{l}\text { 3CL }{ }^{\text {pro }} \\
\text { Inhibitor }\end{array}$} & Tannic acid & $3 \mu \mathrm{M}$ & \multirow[t]{2}{*}{ [73] } \\
\hline & & & $\begin{array}{l}\text { 3- isotheaflavin- } \\
\text { 3-gallate }\end{array}$ & $7 \mu \mathrm{M}$ & \\
\hline Urticaceae & $\begin{array}{l}\text { Urtica dioica } \\
\text { (Stinging } \\
\text { nettle) }\end{array}$ & $\begin{array}{l}\text { Viral spike } \\
\text { protein } \\
\text { inhibitor }\end{array}$ & $\begin{array}{l}\text { Urtica dioica } \\
\text { agglutinin }\end{array}$ & $1.1 \pm 0.4 \mu \mathrm{g} / \mathrm{ml}$ & {$[20,21]$} \\
\hline Zingiberaceae & $\begin{array}{l}\text { Curcuma longa } \\
\text { Isatis }\end{array}$ & $\begin{array}{l}3 \mathrm{CL}^{\text {pro }} \\
\text { Inhibitor }\end{array}$ & Curcumin & $40 \mu \mathrm{M}$ & [51] \\
\hline
\end{tabular}

*IC50 is an indication of the concentration ( $\mu \mathrm{M}$ or $\mathrm{ug} / \mathrm{ml})$ where the activity of the viral protein is reduced up to $50 \%$. EC50 is the indication of the concentration ( $\mu \mathrm{M}$ or $\mu \mathrm{g} / \mathrm{ml}$ ) where the activity of the viral growth is reduced up to $50 \%$. 


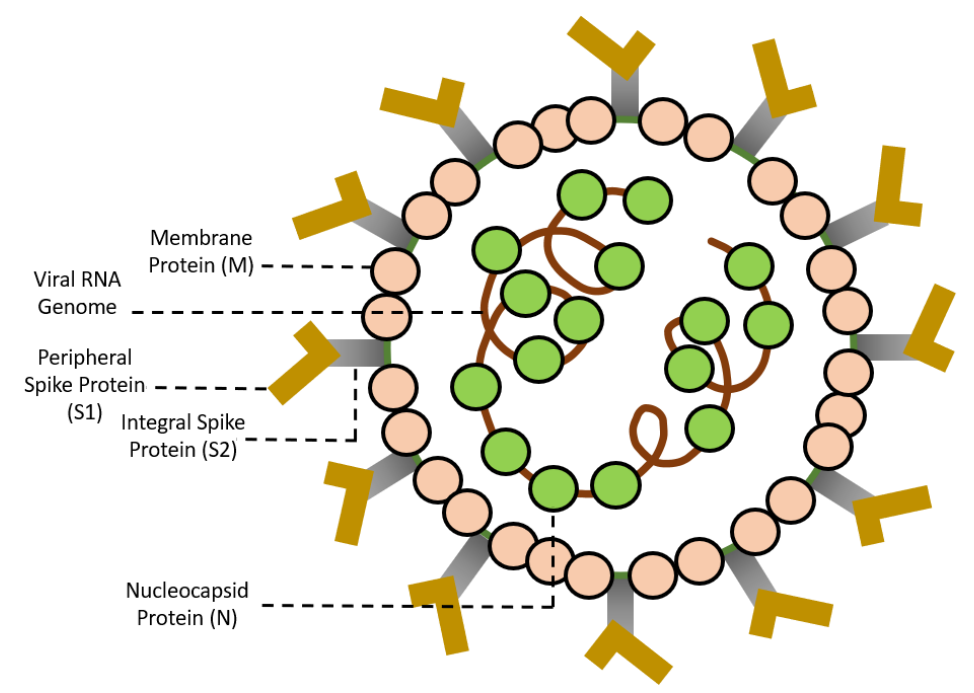

Figure 2. The structure of coronavirus proteins. The spike proteins (S) of the virus are composed of an integral S2 and peripheral S1 protein that is involved in the connection of the virion to the cells. Antibodies against S1 protein will inhibit the propagation of the virus. The nucleocapsid proteins are packaging the viral RNA genome and have an essential role in the viral self-assembly.

\section{Using the plants as oral vaccines}

Application of plants as the vaccines especially with the focus in the oral delivery has numerous advantages such as the lack of viral and bacterial infection in the final product, ease of scaling and benefiting from the bioencapsulation (Storing the expressed protein within the natural environment of the cells) provided by the tissues, cells, and organelles of the cells which bring other advantages such as ease of transport and lowering the logistics fees [74]. Production of vaccines under plant platform against the new coronavirus can be a good solution to the definite massive demand of the world as the scaling of production is easy for plant-based vaccines. Plant cells have this ability to show eukaryotic post-translational modifications which gives them another advantage over usage of bacterial platforms such as E. coli to express and store the proteins. Plants can be employed as a bioreactor for overexpression of a compound that might have anti-viral activity. Consequently, it is a suitable approach to find agents that can be expressed under plant systems to induce the immunological system against the virus in order to have mucosal or long-term immunity. 
Previous studies have focused on the production of a vaccine based on overexpression of the SARSCov surface proteins in the plant species by transformation technics such as bacterial infection and gene gun transformation to express the viral proteins in the plants. Such viral proteins can stimulate the immunity of the host by introducing the antigens to the human body after consumption. The main proteins that are considered by experiments are composed of the S1 subunit of the SARS-Cov spike protein, membrane protein (M) and the nucleocapsid of the virus called N protein (Figure 2). Although there have been studies about the immunological activity of the M protein as a target for plant viral vaccines [72], studies have mainly focused on $\mathrm{S}$ and $\mathrm{N}$ proteins. The genome of $\mathrm{S} 1$ or $\mathrm{N}$ protein can be mounted to a vector and be delivered to the host organism for transcription, expression, and accumulation of the viral antigen [74]. The introduction of the new piece of codon to the plant will finally produce a transgenic plant that is able to express and accumulate the viral $\mathrm{N}$ or $\mathrm{S}$ proteins in the inner segments and organelles of the plant cells of plant tissue. The general overview of the required considerations and challenges for the production of plant vaccines (mainly in seed oral vaccines) has been discussed previously by our group [74]. There are mainly two types of SARS-Cov virus viral antigen proteins that have been aimed to be expressed in the recombinant plant platform, $\mathrm{S} 1$ and $\mathrm{N}$ proteins.

\section{The expression of $\mathrm{N}$ protein}

$\mathrm{N}$ protein is the nucleocapsid protein of the SARS-Cov (Figure 2). It is demonstrated that the antibodies against the $\mathrm{N}$ and $\mathrm{S}$ protein were clearly detected in the patients of the early stages of SARS-Cov disease [34]. It is also discovered that the SARS-Cov N protein was able to induce both temporal and longterm memory T-cell response [33]. For this reason, the $\mathrm{N}$ protein is regarded as one of the effective inductors of the humoral and cellular responses in the SARS-Cov contamination process [33]. Studies for expression of $\mathrm{N}$ protein are mainly done on the tobacco platform. After showing the feasibility of the $\mathrm{N}$ protein expression in Tabaco platform by several pieces of research, it was found that the oral delivery and the injection of the N protein to the BALB-C mice was able to increase respectively the amount of $\operatorname{IgA}$ and $\operatorname{IgG}$ in the experimental mice sera, indicating the Anti-SARS Cov activity of the vaccines [33]. The previous investigation also reveals that the expression of $\mathrm{N}$ protein in the plants can 
be used as a rapid and facile diagnostic tool for SARS-Cov infection. The transgenic expressed oral delivery of the $\mathrm{N}$ proteins have been assessed in the patients with SARS. The $\mathrm{N}$ proteins that were expressed in the tobacco platform using potato virus $\mathrm{X}$ infection were only successfully appeared in the immunoblotting sera of the patients that had SARS-Cov and not any other irrelevant respiratory syndromes [35]. Consequently, the acquired data from the several pieces of research indicates that the expression of the $\mathrm{N}$ protein in the plants can be an introduction to further research for the new coronavirus disease.

\section{The expression of S1 protein}

The expression of the spike glycoprotein of the SARS-Cov is followed by the creation of a large polypeptide that is finally cleaved by proteases that are encoded by the host or virus to S1 and S2 subunits. $\mathrm{S} 1$ is the peripheral part of the virus that is believed to contain the main receptor-binding domain (RBD) on the N-terminal part. It is noticed that the antibodies against S1 protein are strongly efficient in the RBD interaction. Therefore, it is aimed to target the $\mathrm{S} 1$ genes to the part of the cells and organelles within the plants such as tobacco, tomato and lattice platforms.

The previous research for expression of the $\mathrm{S} 1$ protein in the plants proved compelling evidence of the plant's potential to be used as a bioreactor for expression of SARS-Cov viral antigen proteins. The S1 proteins were expressed in the cytosol [30] or chloroplast [31] with an accumulation rate of up to a maximum of $10.2 \%$ of Total Soluble Protein (TSP). The oral delivery of the S1 proteins in the platform of tomato resulted in a significant IgA increase while the injection of the $\mathrm{S} 1$ protein from the dried root of tobacco resulted in a significant detection of the $\operatorname{IgG}$ in western blot and ELISA results [32].

On the whole, the transgenic plants have this potential to provide an approach for the production of plant vaccines against COVID-19 disease. However, the usage of plant cells as a bioreactor is subjective to several ethical and environmental considerations. As this process will result in the generation of a new transgenic plant, it is probable that the propagation of the plant species as the result of the uncontrolled breeding might affect the species within the ecosystems, create an imbalanced niche or 
even cause poisoning to the species that might consume the plant randomly. Consequently, the transgenic plant culture should be done under restricted control [74].

\section{Controlling the plants' anti-viral compounds expression via}

\section{environmental conditions}

Based on the fact that the expression of the lectins and secondary metabolites of the plants are highly dependent on the environmental conditions. Alternatively, it is possible to increase the expression of an anti-viral compound within the plant by changing the environmental circumstances to induce a more stressful condition for the plant. As mentioned earlier in the article some plant species such as tobacco can express anti-SARS lectins that tend to inhibit viral propagation [19]. It is also found that the expression of the lectins in the species such as tobacco can be increased by the presence of pathogens, pest insects and other biochemical materials that could induce the immunogenic response in the plant species. In this case, it is possible to increase the effective lectin content for a higher yield in case of the attitude for non-oral delivery or to increase the effective dose in case of oral delivery [74]. For this reason, the type of pest or invader species [75], the variations in the stress environment [76] and the biochemical (such as Jasmonates) compounds [77] can alter the expression of the lectins in the plants especially in the expression of Nictaba of tobacco. It is worth mentioning that the application of the plant biotechnology technics can also provide the ability of the overexpression of the lectin genes such as UDA and Nictaba agglutinin to provide a higher yield and dosage of the anti-viral compound in the plants.

\section{The effectivity of the anti-viral plants' oral delivery}

In this review, we have recommended various plants that can have the anti-SARS Cov2 potential. However, the oral delivery of such compounds might be further advantageous as oral delivery is facile and non-invasive. In the case of the usage of plants as the vaccines for expression of the anti-SARS Cov agents, it was observed that the oral delivery of vaccines to animal model was able to induce the mucosal immune responses $[32,33]$. Meanwhile, the oral delivery of the plant baicalin was shown to successfully 
reduce the mortality in the influenza-infected mice [25]. However, the question is whether the direct oral delivery of the compounds will be also effective in terms of having antiviral activities. It was confirmed by several studies that most of the plant anti-SARS agents can inhibit the connection of the viral agents to the cells [39]. Therefore it can be postulated that most plant anti-viral agents might apply a protective behavior against the entrance and propagation of the viral agents in the host body. In this case, adding the edible plant species that produce anti-SARS-Cov compounds such as leek, onion, garlic and stinging nettle root (the common nettle) in the food diet might be a good strategy against infection of the new COVID-19 disease.

\section{Conclusion}

Based on the high similarity of the genome and the receptors of SARS-Cov and SARS-Cov2 this review attempted to suggest possible plant species that might be implicated as anti-SARS-Cov2 agents. Plant species can provide a natural, cost effective and with less side effects approaches of drug discovery against COVID-19 disease. Our study suggested the plant species such as $U$. dioica and S. baicalensis might encounter the protection, relief or treatment potential against COVID-19 disease. Among such plant compounds, lectins such as Utrica dioica agglutinin and plant secondary metabolites such as Glycyrrhizin and Baicalin have shown promising results in SARS-Cov as well as a favorable in-silico results in the COVID19 disease. Such compounds might be a good choice for further research toward finding a novel natural treatment approach. Meanwhile, several studies have tried to use the plants as a bioreactor to express the SARS vaccinal agents or to overexpress the vaccinal agents. Perhaps the use of tobacco plant might be a suitable option as numerous studies have demonstrated positive results in production and immunization in-vivo by deployment of the tobacco platform for transformation. Furthermore, tobacco contains NICTABA lectin which is a strong antiviral agent. Overal, more studies are needed in order to further assess the anti-viral ability of plant species.

\section{References}

[1] WHO. "Middle East respiratory syndrome coronavirus (MERS-CoV) " World Health Organization. https://www.who.int/emergencies/mers-cov/en/ (accessed 1/4/2020. 
[2] C. Drosten et al., "Clinical features and virological analysis of a case of Middle East respiratory syndrome coronavirus infection," The Lancet Infectious Diseases, vol. 13, no. 9, pp. 745-751, 2013/09/01/ 2013, doi: https://doi.org/10.1016/S1473-3099(13)70154-3.

[3] T. Que, V. Wong, and K. Yuen, "Treatment of severe acute respiratory syndrome with lopinavir/ritonavir: a multicentre retrospective matched cohort study," Hong Kong Med J, vol. 9, no. 6, pp. 399-406, 2003.

[4] B. Cao et al., "A trial of lopinavir-ritonavir in adults hospitalized with severe Covid-19," New England Journal of Medicine, 2020.

[5] K. Anand, J. Ziebuhr, P. Wadhwani, J. R. Mesters, and R. Hilgenfeld, "Coronavirus main proteinase (3CLpro) structure: basis for design of anti-SARS drugs," Science, vol. 300, no. 5626, pp. 1763-1767, 2003.

[6] K.-C. Chou, D.-Q. Wei, and W.-Z. Zhong, "Binding mechanism of coronavirus main proteinase with ligands and its implication to drug design against SARS," Biochemical and biophysical research communications, vol. 308, no. 1, pp. 148-151, 2003.

[7] X. W. Zhang and Y. L. Yap, "Old drugs as lead compounds for a new disease? Binding analysis of SARS coronavirus main proteinase with HIV, psychotic and parasite drugs," Bioorganic \& Medicinal Chemistry, vol. 12, no. 10, pp. 2517-2521, 2004/05/15/ 2004, doi: https://doi.org/10.1016/j.bmc.2004.03.035.

[8] K. Anand, H. Yang, M. Bartlam, Z. Rao, and R. Hilgenfeld, "Coronavirus main proteinase: target for antiviral drug therapy," in Coronaviruses with special emphasis on first insights concerning SARS: Springer, 2005, pp. 173-199.

[9] Y. M. Báez-Santos, S. E. St. John, and A. D. Mesecar, "The SARS-coronavirus papain-like protease: Structure, function and inhibition by designed antiviral compounds," Antiviral Research, vol. 115, pp. 21-38, 2015/03/01/ 2015, doi: https://doi.org/10.1016/j.antiviral.2014.12.015.

[10] M. Cascella, M. Rajnik, A. Cuomo, S. C. Dulebohn, and R. Di Napoli, "Features, Evaluation and Treatment Coronavirus (COVID-19)," in StatPearls [Internet]: StatPearls Publishing, 2020. 
[11] H. Zhang, J. M. Penninger, Y. Li, N. Zhong, and A. S. Slutsky, "Angiotensin-converting enzyme 2 (ACE2) as a SARS-CoV-2 receptor: molecular mechanisms and potential therapeutic target," Intensive Care Medicine, vol. 46, no. 4, pp. 586-590, 2020/04/01 2020, doi: 10.1007/s00134-020-05985-9.

[12] D. C. Dinesh, S. Tamilarasan, K. Rajaram, and E. Bouřa, "Antiviral Drug Targets of SingleStranded RNA Viruses Causing Chronic Human Diseases," Current drug targets, vol. 21, no. 2, pp. 105-124, 2020.

[13] L. Dong, S. Hu, and J. Gao, "Discovering drugs to treat coronavirus disease 2019 (COVID19)," Drug discoveries \& therapeutics, vol. 14, no. 1, pp. 58-60, 2020.

[14] F. Wu et al., "A new coronavirus associated with human respiratory disease in China," Nature, vol. 579, no. 7798, pp. 265-269, 2020.

[15] P. Zhou et al., "Discovery of a novel coronavirus associated with the recent pneumonia outbreak in humans and its potential bat origin," BioRxiv, 2020.

[16] M. T. ul Qamar, S. M. Alqahtani, M. A. Alamri, and L.-L. Chen, "Structural basis of SARSCoV-2 3CLpro and anti-COVID-19 drug discovery from medicinal plants $\dagger$," Journal of Pharmaceutical Analysis, 2020/03/26/ 2020, doi: https://doi.org/10.1016/j.jpha.2020.03.009.

[17] X. Xu et al., "Evolution of the novel coronavirus from the ongoing Wuhan outbreak and modeling of its spike protein for risk of human transmission," Science China Life Sciences, vol. 63, no. 3, pp. 457-460, 2020/03/01 2020, doi: 10.1007/s11427-020-1637-5.

[18] N. Mohammadi and N. Shaghaghi, "Inhibitory effect of eight Secondary Metabolites from conventional Medicinal Plants on COVID_19 Virus Protease by Molecular Docking Analysis," 2020.

[19] E. Keyaerts et al., "Plant lectins are potent inhibitors of coronaviruses by interfering with two targets in the viral replication cycle," Antiviral research, vol. 75, no. 3, pp. 179-187, 2007.

[20] F. J. U. M. van der Meer et al., "The carbohydrate-binding plant lectins and the non-peptidic antibiotic pradimicin A target the glycans of the coronavirus envelope glycoproteins," Journal of Antimicrobial Chemotherapy, vol. 60, no. 4, pp. 741-749, 2007, doi: 10.1093/jac/dkm301. 
[21] Y. Kumaki et al., "Inhibition of severe acute respiratory syndrome coronavirus replication in a lethal SARS-CoV BALB/c mouse model by stinging nettle lectin, Urtica dioica agglutinin," Antiviral Research, vol. 90, no. 1, pp. 22-32, 2011/04/01/ 2011, doi: https://doi.org/10.1016/j.antiviral.2011.02.003.

[22] F. Chen et al., "In vitro susceptibility of 10 clinical isolates of SARS coronavirus to selected antiviral compounds," Journal of Clinical Virology, vol. 31, no. 1, pp. 69-75, 2004/09/01/ 2004, doi: https://doi.org/10.1016/j.jcv.2004.03.003.

[23] C. F. Yeh, K. C. Wang, L. C. Chiang, D. E. Shieh, M. H. Yen, and J. San Chang, "Water extract of licorice had anti-viral activity against human respiratory syncytial virus in human respiratory tract cell lines," Journal of ethnopharmacology, vol. 148, no. 2, pp. 466-473, 2013.

[24] G. Hoever et al., "Antiviral Activity of Glycyrrhizic Acid Derivatives against SARSCoronavirus," Journal of medicinal chemistry, vol. 48, no. 4, pp. 1256-1259, 2005.

[25] H.-J. Zhi, H.-Y. Zhu, Y.-Y. Zhang, Y. Lu, H. Li, and D.-F. Chen, "In vivo effect of quantified flavonoids-enriched extract of Scutellaria baicalensis root on acute lung injury induced by influenza A virus," Phytomedicine, vol. 57, pp. 105-116, 2019/04/01/ 2019, doi: https://doi.org/10.1016/j.phymed.2018.12.009.

[26] K. Y. Yuen et al., "Baicalin as a treatment for SARS infection," ed: Google Patents, 2009.

[27] A. Massi et al., "Research Progress in the Modification of Quercetin Leading to Anticancer Agents," (in eng), Molecules, vol. 22, no. 8, p. 1270, 2017, doi: 10.3390/molecules22081270.

[28] T. T. H. Nguyen et al., "Flavonoid-mediated inhibition of SARS coronavirus 3C-like protease expressed in Pichia pastoris," Biotechnology Letters, vol. 34, no. 5, pp. 831-838, 2012/05/01 2012, doi: 10.1007/s10529-011-0845-8.

[29] S. Jo, S. Kim, D. H. Shin, and M.-S. Kim, "Inhibition of SARS-CoV 3CL protease by flavonoids," Journal of Enzyme Inhibition and Medicinal Chemistry, vol. 35, no. 1, pp. 145151, 2020/01/01 2020, doi: 10.1080/14756366.2019.1690480.

[30] H.-Y. Li, S. Ramalingam, and M.-L. Chye, "Accumulation of recombinant SARS-CoV spike protein in plant cytosol and chloroplasts indicate potential for development of plant-derived oral vaccines," Experimental Biology and Medicine, vol. 231, no. 8, pp. 1346-1352, 2006. 
[31] X. Zhong, G. Qi, J. Yang, G. Xing, J. Liu, and X. Yang, "[High-efficiency expression of a receptor-binding domain of SARS-CoV spike protein in tobacco chloroplasts]," (in chi), Sheng Wu Gong Cheng Xue Bao, vol. 30, no. 6, pp. 920-930, 2014/06// 2014. [Online]. Available: http://europepmc.org/abstract/MED/25212009.

[32] N. Pogrebnyak et al., "Severe acute respiratory syndrome (SARS) S protein production in plants: development of recombinant vaccine," Proceedings of the National Academy of Sciences, vol. 102, no. 25, pp. 9062-9067, 2005.

[33] N. Zheng et al., "Boosted expression of the SARS-CoV nucleocapsid protein in tobacco and its immunogenicity in mice," Vaccine, vol. 27, no. 36, pp. 5001-5007, 2009/08/06/ 2009, doi: https://doi.org/10.1016/j.vaccine.2009.05.073.

[34] Y. Wang et al., "Profiles of IgG antibodies to nucleocapsid and spike proteins of the SARSassociated coronavirus in SARS patients," DNA and cell biology, vol. 24, no. 8, pp. 521-527, 2005.

[35] R. Franconi, E. Illiano, F. Paolini, S. Massa, A. Venuti, and O. C. Demurtas, "Rapid and LowCost Tools Derived from Plants to Face Emerging/Re-emerging Infectious Diseases and Bioterrorism Agents," in Defence Against Bioterrorism, Dordrecht, V. Radosavljevic, I. Banjari, and G. Belojevic, Eds., 2018// 2018: Springer Netherlands, pp. 123-139.

[36] R. Dhouibi et al., "Screening of pharmacological uses of Urtica dioica and others benefits," Progress in Biophysics and Molecular Biology, vol. 150, pp. 67-77, 2020/01/01/ 2020, doi: https://doi.org/10.1016/j.pbiomolbio.2019.05.008.

[37] E. Ramos-Tovar and P. Muriel, "Chapter 9 - Phytotherapy for the Liver*," in Dietary Interventions in Liver Disease, R. R. Watson and V. R. Preedy Eds.: Academic Press, 2019, pp. 101-121.

[38] J. Cinatl, B. Morgenstern, G. Bauer, P. Chandra, H. Rabenau, and H. W. Doerr, "Glycyrrhizin, an active component of liquorice roots, and replication of SARS-associated coronavirus," The Lancet, $\quad$ vol. 361, no. 9374, pp. 2045-2046, 2003/06/14/ 2003, doi: https://doi.org/10.1016/S0140-6736(03)13615-X. 
[39] H. Pilcher, "Liquorice may tackle SARS," Nature, 2003/06/13 2003, doi: 10.1038/news030609-16.

[40] C. Fiore et al., "Antiviral effects of Glycyrrhiza species," Phytotherapy Research: An International Journal Devoted to Pharmacological and Toxicological Evaluation of Natural Product Derivatives, vol. 22, no. 2, pp. 141-148, 2008.

[41] M. N. Asl and H. Hosseinzadeh, "Review of pharmacological effects of Glycyrrhiza sp. and its bioactive compounds," Phytotherapy Research: An International Journal Devoted to Pharmacological and Toxicological Evaluation of Natural Product Derivatives, vol. 22, no. 6, pp. 709-724, 2008.

[42] J. Pu, L. He, S. Wu, P. Zhang, and X. Huang, "Anti-virus research of triterpenoids in licorice," Bing du xue bao= Chinese journal of virology, vol. 29, no. 6, pp. 673-679, 2013.

[43] H. Chen and Q. Du, "Potential natural compounds for preventing 2019-nCoV infection," Preprints, 2020.

[44] H. Liu et al., "Scutellaria baicalensis extract and baicalein inhibit replication of SARS-CoV-2 and its 3C-like protease in vitro," bioRxiv, p. 2020.04.10.035824, 2020, doi: 10.1101/2020.04.10.035824.

[45] B. T. P. Thuy et al., "Investigation into SARS-CoV-2 Resistance of Compounds in Garlic Essential Oil," ACS Omega, 2020.

[46] L. Chen et al., "Binding interaction of quercetin-3- $\beta$-galactoside and its synthetic derivatives with SARS-CoV 3CLpro: Structure-activity relationship studies reveal salient pharmacophore features," Bioorganic \& Medicinal Chemistry, vol. 14, no. 24, pp. 8295-8306, 2006/12/15/ 2006, doi: https://doi.org/10.1016/j.bmc.2006.09.014.

[47] S. Jo, H. Kim, S. Kim, D. H. Shin, and M.-S. Kim, "Characteristics of flavonoids as potent MERS-CoV 3C-like protease inhibitors," Chemical Biology \& Drug Design, vol. 94, no. 6, pp. 2023-2030, 2019/12/01 2019, doi: 10.1111/cbdd.13604.

[48] S. Zhong, H. Yu, and R. Miller, "Extracts of Scutellaria for the Treatment of Sars," ed: Google Patents, 2008. 
[49] S.-y. Li et al., "Identification of natural compounds with antiviral activities against SARSassociated coronavirus," Antiviral research, vol. 67, no. 1, pp. 18-23, 2005.

[50] C.-W. Lin et al., "Anti-SARS coronavirus 3C-like protease effects of Isatis indigotica root and plant-derived phenolic compounds," Antiviral Research, vol. 68, no. 1, pp. 36-42, 2005/10/01/ 2005, doi: https://doi.org/10.1016/j.antiviral.2005.07.002.

[51] C.-C. Wen et al., "Specific Plant Terpenoids and Lignoids Possess Potent Antiviral Activities against Severe Acute Respiratory Syndrome Coronavirus," Journal of Medicinal Chemistry, vol. 50, no. 17, pp. 4087-4095, 2007/08/01 2007, doi: 10.1021/jm070295s.

[52] L. Yi et al., "Small molecules blocking the entry of severe acute respiratory syndrome coronavirus into host cells," Journal of virology, vol. 78, no. 20, pp. 11334-11339, 2004.

[53] J.-Y. Park et al., "Chalcones isolated from Angelica keiskei inhibit cysteine proteases of SARSCoV," Journal of enzyme inhibition and medicinal chemistry, vol. 31, no. 1, pp. 23-30, 2016.

[54] J.-Y. Park et al., "Diarylheptanoids from Alnus japonica inhibit papain-like protease of severe acute respiratory syndrome coronavirus," Biological and Pharmaceutical Bulletin, pp. b1200623, 2012.

[55] Y. B. Ryu et al., "SARS-CoV 3CLpro inhibitory effects of quinone-methide triterpenes from Tripterygium regelii," Bioorganic \& medicinal chemistry letters, vol. 20, no. 6, pp. 1873-1876, 2010.

[56] Y. B. Ryu et al., "Biflavonoids from Torreya nucifera displaying SARS-CoV 3CLpro inhibition," Bioorganic \& medicinal chemistry, vol. 18, no. 22, pp. 7940-7947, 2010.

[57] M. R. Loizzo et al., "Phytochemical analysis and in vitro antiviral activities of the essential oils of seven Lebanon species," Chemistry \& biodiversity, vol. 5, no. 3, pp. 461-470, 2008.

[58] C.-C. Wen et al., "Traditional Chinese medicine herbal extracts of Cibotium barometz, Gentiana scabra, Dioscorea batatas, Cassia tora, and Taxillus chinensis inhibit SARS-CoV replication," Journal of traditional and complementary medicine, vol. 1, no. 1, pp. 41-50, 2011.

[59] D. W. Kim et al., "Phenolic phytochemical displaying SARS-CoV papain-like protease inhibition from the seeds of Psoralea corylifolia," Journal of enzyme inhibition and medicinal chemistry, vol. 29, no. 1, pp. 59-63, 2014. 
[60] J.-Y. Park et al., "Tanshinones as selective and slow-binding inhibitors for SARS-CoV cysteine proteases," Bioorganic \& medicinal chemistry, vol. 20, no. 19, pp. 5928-5935, 2012.

[61] R. Y. Utomo and E. Meiyanto, "Revealing the Potency of Citrus and Galangal Constituents to Halt SARS-CoV-2 Infection," 2020.

[62] Z. Chen and T. Nakamura, "Statistical evidence for the usefulness of Chinese medicine in the treatment of SARS," Phytotherapy Research: An International Journal Devoted to Pharmacological and Toxicological Evaluation of Natural Product Derivatives, vol. 18, no. 7, pp. 592-594, 2004.

[63] M.-S. Yu et al., "Identification of myricetin and scutellarein as novel chemical inhibitors of the SARS coronavirus helicase, nsP13," Bioorganic \& medicinal chemistry letters, vol. 22, no. 12, pp. 4049-4054, 2012.

[64] M. Zhuang et al., "Procyanidins and butanol extract of Cinnamomi Cortex inhibit SARS-CoV infection," Antiviral research, vol. 82, no. 1, pp. 73-81, 2009.

[65] S. Jo, H. Kim, S. Kim, D. H. Shin, and M. S. Kim, "Characteristics of flavonoids as potent MERS-CoV 3C-like protease inhibitors," Chemical biology \& drug design, vol. 94, no. 6, pp. 2023-2030, 2019.

[66] D. Chattopadhyay, "Role and Scope of Ethnomedical Plants in the Development of Antivirals," Pharmacologyonline, vol. 3, pp. 64-72, 2006.

[67] J. K. Cho et al., "Geranylated flavonoids displaying SARS-CoV papain-like protease inhibition from the fruits of Paulownia tomentosa," Bioorganic \& medicinal chemistry, vol. 21, no. 11, pp. 3051-3057, 2013.

[68] W. Luo et al., "Anti-SARS coronavirus 3C-like protease effects of Rheum palmatum L. extracts," Bioscience trends, vol. 3, no. 4, 2009.

[69] T.-Y. Ho, S.-L. Wu, J.-C. Chen, C.-C. Li, and C.-Y. Hsiang, "Emodin blocks the SARS coronavirus spike protein and angiotensin-converting enzyme 2 interaction," Antiviral Research, vol. 74, no. 2, pp. 92-101, 2007/05/01/ 2007, doi: https://doi.org/10.1016/j.antiviral.2006.04.014. 
[70] K.-M. Lau et al., "Immunomodulatory and anti-SARS activities of Houttuynia cordata," Journal of Ethnopharmacology, vol. 118, no. 1, pp. 79-85, 2008/06/19/ 2008, doi: https://doi.org/10.1016/j.jep.2008.03.018.

[71] K. Fung et al., "Immunomodulatory activities of the herbal formula Kwan Du Bu Fei Dang in healthy subjects: a randomised, double-blind, placebo-controlled study," Hong Kong medical journal= Xianggang yi xue za zhi, vol. 17, p. 41, 2011.

[72] O. C. Demurtas et al., "Antigen production in plant to tackle infectious diseases flare up: the case of SARS," Frontiers in plant science, vol. 7, p. 54, 2016.

[73] C.-N. Chen et al., "Inhibition of SARS-CoV 3C-like protease activity by theaflavin-3, 3'digallate (TF3)," Evidence-Based Complementary and Alternative Medicine, vol. 2, no. 2, pp. 209-215, 2005.

[74] M. YONESI, A. REZAZADEH, and M. M. MOUSAI, "THE CONSIDERATIONS AND THE REQUIRED STEPS FOR PRODUCTION OF THE PLANT SEEDS VACCINES WITH FOCUS ON THE ORAL DELIVERY," PLANT CELL BIOTECHNOLOGY AND MOLECULAR BIOLOGY, pp. 36-51, 2020.

[75] G. Vandenborre, K. Groten, G. Smagghe, N. Lannoo, I. T. Baldwin, and E. J. Van Damme, "Nicotiana tabacum agglutinin is active against Lepidopteran pest insects," Journal of experimental botany, vol. 61, no. 4, pp. 1003-1014, 2010.

[76] S. Van Holle, G. Smagghe, and E. J. Van Damme, "Overexpression of Nictaba-like lectin genes from Glycine max confers tolerance toward Pseudomonas syringae infection, aphid infestation and salt stress in transgenic Arabidopsis plants," Frontiers in plant science, vol. 7, p. 1590, 2016.

[77] A. Delporte, N. Lannoo, G. Vandenborre, M. Ongenaert, and E. J. M. Van Damme, "Jasmonate response of the Nicotiana tabacum agglutinin promoter in Arabidopsis thaliana," Plant Physiology and Biochemistry, vol. 49, no. 8, pp. 843-851, 2011/08/01/ 2011, doi: https://doi.org/10.1016/j.plaphy.2011.04.011. 